Revista del Centro de Investigación de la Universidad La Salle

Vol. 13, No. 50, julio-diciembre, 2018: 69-108

DOI : http://dx.doi.org/10.26457/recein.v13i50.1516

\title{
La Célula, La Estrella y el sano sentido común en Franz Rosenzweig
}

\section{The Cell, The Star, and healthy common sense in Franz Rosenzweig}

\author{
Saúl Daniel Kuri Herrera ${ }^{1}$ \\ Escuela Normal Experimental "Rafael Ramírez Castañeda" (México)
}

Recibido: 16 de octubre de 2018

Aceptado: 08 de abril de 2019

Publicado: 19 de junio de 2019

\section{Resumen}

Importa comprender la precedencia que el sentido común y La Estrella de la Redención de Franz Rosenzweig tienen respecto a la redacción de la "Célula originaria" de la estrella de la redención. Subrayo la palabra "precedencia". Creo, demostrar, en efecto, que a pesar de que la "Célula originaria" sea considerada como "comienzo", en realidad es "posterior" a la estrella a la que apunta, de la misma manera que es "posterior" al sentido común que la impulsa. "Aquello" que origina a la Célula no tiene su origen en ella. Tiene "otro origen" que coincide - a la vez- con el sentido común y con La Estrella de la Redención. La Célula cabe en el orbe de la obra mayor, tanto en el sentido implicado en las figuras separadas que

\footnotetext{
${ }^{1}$ Email: sauld.kuri@outlook.com
}

\section{(@) $\odot \Theta \odot$}

Revista del Centro de Investigación. Universidad La Salle por Dirección de Posgrado e Investigación. Universidad La Salle Ciudad de México se distribuye bajo una Licencia Creative Commons Atribución-NoComercial-Compartirlgual 4.0 
Kuri, Saúl

componen la obra, como en la figura completa de ésta. La Estrella de la Redención destensa lo expuesto en tensión a través de la Célula, y el sentido común impulsa a la reapropiación de los contenidos que ofrece al autor el mundo de la experiencia.

Palabras clave: Embrión; anteceder; figura (s), Elementos; Ruta 


\section{Abstract}

It is important to understand the precedence that the common sense and The Star of the Redemption of Franz Rosenzweig have regarding the drafting of the "Original Cell" of the redemption star. I underline the word "precedence". I think to prove actually in spite of that the "original cell" is considered as "beginnig", in fact is "subsequent" to the star points at, in the same way that is it "subsequent" to the common sense that drives. "That" which originates the Cell does not have origin in it. Has "another origin" which coincides - at the same timewith common sense and The Star of the Redemption. The Cell fits into the orb at the main work, both in the same involved in the separate figures that compose the work, as the complete figure of this. The Star of the Redemption relaxes the exposed in stress even through by the Cell, and common sense drives to the reappropiation of the contents that offers to the author the world of experience.

Keywords: Embryo; to precede; figure (s), Elements; Route 


\section{Introducción}

Este trabajo enmarca un amplio estudio en el que trato de mostrar el significado y la función que tiene el sentido común en el pensamiento de Franz Rosenzweig, de manera concreta, en la epístola a la postre intitulada "Célula originaria" de la estrella de la redención y, de manera general, en La Estrella de la Redención. Forma parte de una investigación que comienza de la mano de una tesis expuesta por el mismo Franz Rosenzweig, quien dice en El nuevo pensamiento que lo que su pensamiento plantea no es otra cosa que lo que el sentido común enseña, y a partir de la cual intento mostrar que el sentido común -tal y como el autor sostiene en El libro del sentido común sano y enfermo y El nuevo pensamiento- es patente en la Célula originaria. Tal investigación -en un principio- quise desarrollarla centrándome en La Estrella de la Redención, el acercamiento a la Célula originaria se consideró como un paso en esta dirección. No obstante, en el esfuerzo de elucidar esta última, poniéndola en relación con el sentido común, terminé enfocándome en ella. Lo que sería tan sólo un primer paso -o un capítulo- pasó a convertirse en el centro de la indagación.

De acuerdo con lo anterior -en términos generales- en este escrito procuro poner de manifiesto la relación concomitante y compleja que tienen la epístola, la obra magna y el que el autor judío llama "sano sentido común". Se trata de una propuesta de comprensión que pone de relieve la exacerbación del sentido presupuesto no sólo en el "origen” de la obra magna, sino en general en la puesta en escena de este pensamiento, y que tiende -conforme avanza el escrito- a atenuar la imbricación de los temas en éste explícitos, para terminar, afirmando la peculiaridad del saber del sentido común y la no-indiferencia de una figura que tiene la forma de estrella. En tal sentido, es de interés -quizá- resaltar que este artículo no se concentra en avanzar hacia la discusión de los temas de la carta, tampoco en ahondar explícitamente en el contenido de los escritos que cito. Como señalo al principio del párrafo precedente, este trabajo enmarca y no tiene prisa en caminar hacia las dificultades más acuciantes de la epístola o de las obras centrales de Rosenzweig. Ello lo he realizado centrado en la misiva - en otro lugar (Kuri, 2018b). Aquí, por hacer expresa una "metodología" apelo a un modelo de racionalidad atento al binomio origen-originado, a partir de este binomio afirmo en lo implicado "aquello" que trae implicaciones: en la escritura 
de la Célula originaria cabe notar "otro origen"; no sólo el "principio" de algo ( $L a$ Estrella...), sino también y en cierto sentido un "resultado". En el ámbito originario en el que está implicada la subjetividad del autor lo que puede parecer "origen" o "inicio" sólo lo “es” por algo que lo permite. El origen originado en la Célula tiene "otro origen”, y éste coincide lo mismo con la estrella a la que la epístola señala que con ese "otro modo de pensar" que con Rosenzweig llamo "sano sentido común”.

Así pues, partiendo de la Célula originaria, reflexiono sobre lo que está implicado en "su concepción”, así como en la figura de triángulo que alcanza a distinguirse casi al término del escrito. El que Franz Rosenzweig llama “sano sentido común”, y las figuras de triángulos que configuran La Estrella de la Redención (la primera figura apuntando hacia arriba y la segunda apuntando hacia abajo, y que corresponden al primero y segundo volumen de la obra, respectivamente, al triángulo de los Elementos Dios, Mundo y Hombre, y al de la Ruta Creación-Revelación-Redención), comunican sobre lo implicado en la "concepción" de la Célula originaria. La obra capital de Franz Rosenzweig, escrita “después” de la epístola, antecede y clarifica lo que está en juego en ésta, a saber: el intento de "deslindar la revelación de todo otro conocimiento propiamente humano, de manera puramente filosófica o siquiera mediante cualesquiera criterios demostrables" (Rosenzweig, 2007a, p.57). Y esto, hasta poder afirmar que, la misiva, que precede a la redacción de La Estrella, es distendida y encuentra cabida en ésta. El conflicto entre el mundo pagano y el mundo revelado, manifiesto en la escritura de la Célula: en el conflicto para poder pensar de una "nueva manera" la revelación, señala hacia aquello "posterior” (la redacción de La Estrella...), que tiene a su vez su "ser anterior". Los Elementos fácticos con que convive el sentido común pagano (Dios, Mundo y Hombre), y la Ruta con la que convive el sentido común judío (CreaciónRevelación-Redención), preceden a la meditación llevada a cabo en la Célula originaria. Y así también lo hace la estrella de David, que Rosenzweig retoma como "estampa" de "su pensamiento". ${ }^{1}$

De acuerdo con lo dicho, en el artículo que presento pongo de manifiesto aquello que precede a la Célula originaria, hago hincapié en el origen conflictivo de la epístola, concebida en medio del encuentro - o desencuentro- entre el mundo de la filosofía y el mundo de la vida judía. Subrayo, el anteceder "inmediato" de la Célula originaria presente en la misma formulación de la epístola, en la resolución de Rosenzweig a pensar "en el medio de 
la filosofía" en "aquello" del mundo vivo judío que le comunica (la revelación); y, subrayo también la antecedencia de La Estrella de la Redención y del sentido común, que fungen de guías y de apoyo en la elucidación de cuanto está en disputa en la Célula originaria. Creo demostrar, en efecto, que la Célula originaria expresa en su escritura los mundos en conflicto que la integran, y que la revelación (que la epístola busca pensar de una "nueva manera") vislumbra, o, mejor, justifica, lo mismo las figuras que contribuyen a explicarla como aquel “otro modo de pensar" (el sentido común) que la estimula y acompaña.

Tanto la obra mayor del autor judío como el sentido común, estimulan a la comprensión de los contenidos implicados en la figura de triángulo que se distingue casi al término de la epístola, y en la orientación de los motivos que justifican el uso de "nociones" e "ideas" en apariencia ajenas al lenguaje de la filosofía que predomina en la época en que Rosenzweig escribe. Lo que está anudado y en tensión a través de la Célula originaria, puede ser desanudado y/o distendido atendiendo a la configuración de La Estrella de la Redención y al sentido común. "Aquello" que antecede a la Célula originaria, y que está en conflicto en ésta, tiene cabida y “es ordenado” en la configuración de La Estrella de la Redención. Por eso, si bien, es lícito decir que cuanto está en juego en la Célula originaria cabe en La Estrella de la Redención, ello en lo absoluto significa que se pueda equiparar el anteceder de aquélla con la antecedencia de ésta. La figura de estrella precede a la disputa que Rosenzweig tiene con la filosofía, pero esta disputa es el resultado del anteceder "inmediato" del autor, que, tras haber seguido sus "talentos" para la filosofía y haber estado a punto de convertirse al cristianismo, decide seguir al judaísmo. ${ }^{2}$

Una gama de temáticas acompaña esta meditación con el propósito de alcanzar a vislumbrar lo que me propongo. Todo lo señalado hasta aquí busco mostrarlo a través de cinco apartados en los que expongo lo siguiente:

En primer lugar, justifico tanto el título de este artículo como la estructura que tiene el mismo. Frente a la convicción de Rosenzweig de que la Célula originaria en la forma que fue escrita podría ser insoportable, acometo la tarea de intentar contribuir a su comprensión partiendo de lo que sobre "su pensamiento" dice el autor judío en los breves escritos que siguen al término de la obra magna y, a la vez, apelando a la comprensión que brinda -en general- ésta. Así resalta y se pone en la mira que el "antes" de la Célula no precede el 
"antes" en que ésta se inscribe. La epístola permite interrogar sobre lo que la origina. La filosofía y "otro modo de pensar" en ella se implican. Y todo ello en su conjunto estimula a la vía que sigue el presente manuscrito.

En segundo lugar, a partir de un sucinto análisis gramatical de las palabras que le dan título a la epístola, procuro mostrar el carácter que tiene en este trabajo la misma. Lejos de considerar a la misiva como "el principio" de la obra después elaborada, aquí la considero tan sólo como embrión, y, por cierto, como embrión concebido por aquello que lo provoca. Filosofía y judaísmo preceden al autor, y también lo hacen La Estrella de la Redención y el sentido común. Si a partir de La Estrella de la Redención es posible elucidar y comprender mejor a la Célula originaria, a partir del sentido común es posible notar por qué es que Rosenzweig se da a la tarea de pensar en la revelación. La elección de la estrella de David como figura a través de la cual Rosenzweig expone "su pensamiento", ilumina desde "su antes" el presente en que surge el embrión, la no-indiferencia de esta figura prueba el impulso del sentido común, y también lo hacen las figuras de triángulos que configuran al escrito central del autor. Por esto último, si en lo hasta aquí expuesto me centro principalmente en la Célula originaria, en esta parte giro a La Estrella de la Redención y, de manera central, al significado que tienen para este pensamiento las figuras de triángulos que componen la obra. Esto último, y que enfatizo al final del apartado, es el punto de partida del siguiente: los triángulos que prestan figura a La Estrella de la Redención reflejan el mundo pagano y el mundo de la revelación.

En tercer lugar, como al final del apartado anterior lo anticipo, pongo de relieve que el sentido común permite ser pensado en La Estrella de la Redención, tanto en los términos del paganismo como en los términos de la revelación. De acuerdo con esto, destaco la estructura general que tiene la obra en sus dos primeros volúmenes y, de paso, el sentido que tiene para este trabajo la figura de estrella. Las referencias hechas a la primera y a la segunda figura o triángulo, y a la "estrella completa" (que en la obra corresponden al primero, segundo y tercer volumen de la obra, respectivamente), fungen de "coordenadas generales" para la comprensión del pensamiento del autor, para la clarificación de lo que está anudado en la Célula originaria, y, por supuesto, para notar el viraje que puede advertirse en este pensamiento que se mueve de Atenas a Jerusalén. Mundo pagano y mundo revelado comparten sentido común, y el lugar asignado al Logos - capaz de integrar a la revelación- 
define el punto de vista por medio del que lo extrarracional escapa a lo racional o, por el que lo extrarracional se pone al "servicio" de lo último.

En cuarto lugar, regresando - de paso- a la Célula originaria, hago notar cómo es que estamos ante un pensamiento que apela al "derecho legítimo" del ser humano a expresarse en "sus propias palabras", y que, en tal sentido debe comprenderse la referencia al "término" revelación. Aquello a que apunta el título de la epístola está en el inicio de ésta, de la misma manera que lo está el sentido común; pero, ello en lo absoluto significa que estemos ante un pensamiento sentado sobre "verdades establecidas", ajeno a la "seriedad" que la filosofía de Hegel se adjudica. El camino por el que Franz Rosenzweig intenta "romper" con la filosofía de Hegel, y, en general, con el idealismo especulativo en su conjunto, apunta a la singularidad de un saber que reivindica la experiencia humana, el testimonio de la novedad e irrepetibilidad del suceso. Se trata de un saber que no se considera poseedor de "una verdad absoluta", esencial o en algún sentido intemporal, y, ello, de manera fundamental, porque ni piensa bastarse a sí mismo, ni se concibe tampoco condenando desde ninguno de sus sentidos. La posición de Rosenzweig frente a Hegel en torno al "sano sentido común", barrunta el camino de ruptura que habrá de probarse en la obra del pensador.

En la quinta y última parte, abundo en lo previamente expuesto en la totalidad del trabajo. Se trata de mostrar que la elección de la figura de la estrella de David como "estampa simbólica" del universo judío no es arbitraria, y que esto bien lo sabe Franz Rosenzweig, quien obrando de acuerdo a la confianza del mundo judío, no abandona los "contenidos" de dicho universo. La referencia a la estrella de David, al término del estudio, pone sobre la mira el viraje que arriba anticipo, y que, yendo de Atenas a Jerusalén, permite apelar al "derecho legítimo" del ser humano a confiar en sus propias palabras y experiencias. Dicha estrella, al final del recorrido, señala en su no indiferencia a la vida y la obra de Franz Rosenzweig, quien pone sobre nuestra mira un pensamiento cuyo eje interpretativo tiene su origen no en los griegos sino en la Biblia. En absoluto estamos ante un saber limitado al universo veterotestamentario, judío o cristiano, sino ante uno abierto al universo pagano y sus sucedáneos.

A la introducción y a las cinco partes en las que está divido el presente trabajo, sumo algunas "consideraciones finales" y "aportes" del mismo. 


\section{De una mirada insoportable y una enseñanza siempre pensada}

A punto de escribir las últimas palabras de la epístola a la posteridad intitulada "Célula originaria" de la estrella de la redención, escrita en el frente de batalla alemán a mediados de noviembre de 1917, Franz Rosenzweig le hace saber a su primo Rudolf Ehrenberg, que su escrito está formulado sólo para él, que ha sido escrito, eis se blépon (mirando hacia ti), y así advierte: "guárdalo para ti: en esta forma, ninguna otra mirada lo soportaría" (2007a, p. 72). Cuatro años después, en el año de 1921 es publicada La Estrella de la Redención, y casi de inmediato El libro del sentido común sano y enfermo, pequeño "manual" en el que el autor se da a la tarea de intentar elucidar en tono "sencillo" lo expuesto en la obra recién terminada. En 1925, tras haber llevado a su realización plena las anotaciones formuladas en la Célula, de exponerlas de manera detallada en La Estrella de la Redención, y de escribir el "manual simplificado" de ésta, será publicado El nuevo pensamiento, brevísimo tratado en el que Rosenzweig (2005) dirá de su pensamiento que no imagina "haberlo inventado, ni tampoco ser él el único en enseñarlo", sino que, "antes bien, el sano entendimiento humano siempre ha pensado así" (p. 15). Sin embargo, tan pronto se ingresa en La Estrella de la Redención y ésta de inmediato lo desborda a uno, la aseveración del autor -en el sentido de que su pensamiento no hace sino exponer lo que el sano entendimiento siempre ha pensadoprovoca, despierta dudas, despierta inquietudes, invita a probar si en efecto lo dicho puede sostenerse.

Tanto El libro del sentido común sano y enfermo como El nuevo pensamiento, en proporción diferente y en tono distinto, hacen notar que en la obra mayúscula está de por medio implicado el "sano sentido común", que, en ambos escritos es definido de cara a aquello que no lo caracteriza. Prolegómenos de la obra terminada, dichos manuscritos responden al respeto del autor por el lector: en absoluto se trata de poner en duda el saber del sentido común, que es vislumbrado y enfatizado como saber importante. Consciente de la manera en que fue recibida La Estrella de la Redención, Rosenzweig escribe dos tratados con tonos distintos. En El libro del sentido común sano y enfermo trata a los seguidores de los viejos sistemas de filosofía como pacientes que podrían curarse, haciéndolo subraya la preeminencia y el funcionamiento del también llamado "sano entendimiento humano": no evita redactar advertido del rechazo al que es propenso el planteo de "su pensamiento"; al 
contrario, la misma propensión a este rechazo es tratada en el conjunto de la exposición. En El nuevo pensamiento, que para Rosenzweig no es otro que el del "sano sentido común", soslaya hacerse cargo de responder al rechazo de su obra mayor. Prefiriendo dirigir la palabra al "recibimiento cordial" que ésta encontró -y puede encontrar todavía hoy-, se vuelca a una exposición en la que al tiempo de mostrar la estructura general de la misma introduce en ella.

Tanto en El libro del sentido común sano y enfermo como en El nuevo pensamiento la configuración de La Estrella de la Redención es expuesta de manera "simplificada", procurando clarificar su dificultad de la mano del "sano sentido común", que puesto en el inicio de los dos tratados late y avanza atento al tiempo y al otro. En la redacción de los dos pequeños textos la atención a la gramática y a la experiencia humana resalta: el uso del pronombre personal en singular y plural, la meditación sobre la duración del nombre, sobre el nombramiento y el testimonio; la mostración de la impermutabilidad de las facticidades Dios, Mundo y Hombre, la experimentabilidad de sus relaciones; son, en fin, algunos de los “temas" en estas introducciones que confirman lo expreso en la configuración de La Estrella de la Redención. Oponiendo el sentido común sano o nuevo pensamiento al sentido común enfermo o viejo pensamiento, Rosenzweig advierte sobre la tentación de seguir preguntando a la manera en que este último lo hace: buscando la substancia o el ser esencial, definiendo y diciendo "lo que es", guiando la vida o, mejor, deteniéndola ahí donde el "sentido común sano" camina y agradece sus días; testimoniando las realidades efectivas que abraza sin adjudicárselas o anularlas al gusto, que acepta en su des-quite y sin socavarlas en la singularidad de su nombrar; a título de la "altura" del "preciso saber" o de lo que es "preciso re-conocer". No obstante, apenas uno ingresa en La Estrella de la Redención y de inmediato resalta el exceso de sentido que invita no sólo a probar si lo dicho en los prolegómenos puede sostenerse, sino también, que invita a pensar en los caminos a través de las cuales podría esto mostrarse.

La advertencia que Franz Rosenzweig hace a Rudolf Ehrenberg al final de la Célula, presupone la conciencia en el que remite de la dificultad que ha debido de pasar su destinatario. Permite atisbar que algo habrá de saldarse y, en la mira de esto que habrá de saldarse, permite también pensar si puede en verdad -el sentido común- prestar su ayuda a la elucidación de lo expuesto en la Célula originaria y, en general, en este pensamiento. La 
Célula originaria, escrito que requiere "de una gran dosis de buena voluntad para entenderlo" (Rosenzweig, 2007a, p.72), posee en sí misma elementos que contribuyen a su comprensión, pero que se avistan mejor desde su "corolario" directo, y -claro está- desde los prolegómenos hechos a dicho "corolario", haciendo posible que el lector pueda leer sus líneas sin que éstas parezcan insoportables. La comprensión general de La Estrella de la Redención (o, si se quiere mejor, la comprensión general del modo en que ésta está configurada), permite elucidar la intrincada escritura de la Célula originaria, y la afirmación -posterior- de que estamos ante un pensamiento que no hace sino exponer lo que el sentido común siempre ha pensado, permite vislumbrar la dirección y el sentido implicado en lo que admite ser elucidado. La epístola, que precede por algunos años a la obra mayor, que incluye a grandísimos rasgos lo que en ésta se habrá de esclarecer, evoca desde su título "el inicio" de lo que después habrá de mostrarse. No obstante, hay que hacer notar, que dicho título evoca también un anteceder en que la misiva se inscribe, y que hace de ésta un paso al interior del universo que la hace posible, justificándola como una "primera concepción”, más no como "la concepción" misma de la obra mayor. Si aquí entrecomillo "corolario" (cuando hago referencia a La Estrella...), de la misma manera que "origen", "inicio", o "primera concepción" (cuando hago referencia a la Célula originaria), no es porque carezca de propósito. Es que, ese "antes" que la misiva subraya, no precede al "antes" en que ésta se inscribe. En el nombre de la epístola a la postre reconocida como "Célula originaria" de la estrella de la redención, está presupuesto un momento anterior a la redacción de $L a$ Estrella...; dicho momento se caracteriza como embrión, y sólo como tal ha de comprenderse, procediendo de algún lugar o dando origen a algo, pero, en absoluto definiendo el sentido y el origen de la estrella a la que apunta.

La epístola aquí referida, al tiempo en que señala a algo que ella origina, permite -a la vez- interrogar sobre aquello que la origina. En al menos dos sentidos, la carta tiene su germen en la filosofía: nace en un medio marcado por ésta, por una época que, para Rosenzweig, va de Jonia a Jena; es inseparable de la inteligencia, dispuesta a explicar lo que "se desea" (en el caso de la misiva, el esbozo de una "nueva manera" de pensar en la revelación). Ninguna de estas cosas significa que su origen sea solamente resultado de la filosofía. Antes bien, hay algo más. Algo que también la origina y está implicado en su 
escritura. En la redacción de la misiva escrita en las trincheras del frente alemán, asoma “otro modo de pensar".

No es insignificante hablar, tomar la palabra para dirigirla a otro. Mucho menos, si esto sucede en la guerra, en el campo de combate en el que los obuses retruenan: obligando al ser humano a esconderse "como un gusano en los repliegues de la tierra desnuda" (Rosenzweig, 1997, p.43). Frente a las secuelas y consecuencias de la filosofía antecedente, que ordena lo singular (o lo desaparece) en el Todo que lo envuelve, Rosenzweig reivindica al ser humano singular, que descubre en y fuera del lenguaje de la filosofía "otro modo de pensar". Este "otro modo de pensar", que también sirve de germen a la Célula originaria, y que está implicado en su escritura, no es sino una experiencia singular de alcance universal. Esta experiencia singular de alcance universal precede a su negación, no es otra cosa que la del "sano sentido común", y La Estrella de la Redención, la obra capital de Franz Rosenzweig, puede ser vislumbrada como su demostración.

\section{Del "origen" del embrión y lo que a éste antecede}

La "Célula originaria" de la estrella de la redención, como su nombre lo indica, se presenta como "embrión originario" de una figura en la forma de estrella. Sin embargo, como se ha adelantado desde la introducción y el apartado anterior, aquí lo que "se presenta" no se circunscribe a "su concepción". Significativas son las palabras con las que está titulada la epístola. El sustantivo ("célula") al principio del título evoca su vida propia, así como su disposición y función al interior de una organización mayor en la que contribuye. El adjetivo "originaria" ha de entenderse en su doble acepción, como algo que da origen a algo o como algo que procede o participa de algo. El sustantivo no es propiedad de Rosenzweig y así lo subraya el adjetivo, y si acaso es posible sesgar su sentido constituyéndolo en una suerte de "principio", es por la preposición (“de”) a la que apunta el artículo determinado ("la"). Éste desemboca en un sustantivo (f), en una estrella que como tal evoca a su resplandor, a su fulgor y poder brillar con luz propia, apuntando de esta manera a la redención y dirigiéndose así a la redención. Estamos ante una unidad en la etapa inicial de su desarrollo, no ante un producto arbitrario, sino sólo ante el comienzo de algo que ha podido plantearse y avistarse como una "gran conversión" del pensador judío en el "terreno del entendimiento". 3 El 
embrión "no debe 'su ser' a sí mismo”, se encuentra en un lugar determinado, es en cierto modo el resultado del medio que permitió gestarlo. No sobra decir que el embrión ("La Célula") apunta a su nacimiento, a su desarrollo y maduración, que ha de hacer frente a lo que le impide sostenerse para, por el camino difícil -del hombre docto- poderse pensar, ya no como "principio" sino como "un momento" al interior de un camino que hace partícipe de sí, empujando a la realización de una figura que, pudiendo parecer "resultado", está empero desde "el inicio" en el que ella se articula.

La Célula originaria es indisociable del mundo en que surge, del horizonte en que pudo pensarse. No está "antes" de los motivos que permitieron gestarla. Tiene su cimiento en el encuentro, o mejor, en el desencuentro entre la tradición de la filosofía y la tradición judía. Sin embargo, es necesario advertir que es el influjo de la tradición judía el que impulsa a la redacción de la epístola, que es la convicción del autor en la vitalidad de dicha tradición la que motiva a la reapropiación de las enseñanzas contenidas en ésta (Kuri, 2018a). Sentido común de un pensador judío comprometido con el rigor, tanto de las exigencias como de las experiencias propias del judaísmo, a saber: no olvidar el judaísmo de la fe que testimonia sus respuestas, no permitir ser aislado en el gueto o refugiarse en éste eludiendo el mundo que lo confronta. Todo lo contrario. Se trata de recuperar lo caído en olvido, mostrar la universalidad de "eso que ha sido aislado", sea a título del particularismo legalista -siempre recurrente-en la historia del judaísmo, y contra el cual los profetas se rebelan, sea por el juicio de los pueblos sumergidos en la Historia. Enfrentar el mundo que parece resuelto a todo disolverlo, a todo engullirlo en su seno. En fin, procurar salvaguardar, dotar de vigor y de sentido los contenidos de la experiencia del ser humano singular, y, delante de las tendencias que las aplastan o las maltratan.

Sin duda, a la Célula originaria la antecede tanto la filosofía como el judaísmo. Su “concepción” es "el resultado" del contacto entre estos saberes, surge en el medio en que se gesta. No cabe decir lo mismo de La Estrella de la Redención. La Célula originaria no es La Estrella de la Redención. Ésta explica cuanto está implicado en el embrión, muestra que "su antecedencia" (de La Estrella...) precede a las disputas suscitadas en el campo de la filosofía, que tales disputas no son sino sólo un momento que puede advertirse en su misma configuración (primer volumen de la obra). El embrión es sólo "un momento" al interior de la figura de estrella que -en su configuración- incluye los debates que el pensador judío 
sostiene con la filosofía. Se presenta al debate porque ella está "originada" en ésta (en la filosofía), de la misma manera que lo está de la "no-filosofía” de la tradición judía. Es decir, por aquel "saber no-filosófico" -y presente en la vida del judaísmo- para el que la filosofía a pesar de su importancia no es lo fundamental. Y ello, no sólo porque "para el judaísmo la doctrina oral es más antigua y más santa que la escrita” (Rosenzweig, 1997, p. 212), sino también, porque más importante que toda concepción particular y dirimente de los problemas es el "día a día de la vida".

Tal es el cuño en que surge. Su meditación se nutre de ambas tradiciones, pero ante todo, que más allá de las disputas y los contenidos implicados en su escritura, se puede advertir en ella aquel "otro origen que la dirige". El "origen conflictivo" del embrión da "origen a algo", a la conciencia de un pensamiento que tiene a su vez "otro origen". Este "otro origen" no descansa en la "estancia" en que se salda el debate entre el pensamiento de la filosofía y el pensamiento de la tradición judía. Este "otro origen" no es otro que el que Franz Rosenzweig llama “el sano entendimiento humano" o "sano sentido común”, que incita al ser humano singular a la reapropiación de los contenidos de sus experiencias, y no a abandonar la fecundidad, fortaleza y sencillez de éstas. Lo que aquí se plantea como resultado es un embrión que habrá de madurar, pero ello no significa que "lo madurado" sea también "resultado". Si de la Célula originaria cabe decir que es "resultado", no cabe decir lo mismo de La Estrella de la Redención. A partir de La Estrella de la Redención es posible elucidar a la Célula originaria, concebir la forma en que ésta fue escrita, apuntar a la clarificación de lo que en la epístola se problematiza. A partir del sentido común es posible entender los motivos que llevan a Rosenzweig a pensar en la revelación, punto de Arquímedes filosófico del autor (2007a, p.57) y, asimismo, en todas esas palabras que evocan -en el interior de la epístola- un lenguaje "ajeno" a la filosofía.

Efectivamente, en la Célula originaria se puede notar no sólo el conflicto entre los universos que la anteceden, sino la "superación" misma de este conflicto por el realce de algo que se encuentra a la base, y que incita a la reapropiación de las "propias palabras", a la "superación" de lo que impide poder afirmarlas. Ahora bien, esta "superación" no ha de entenderse en sentido hegeliano, pues no busca "reconciliar" los opuestos en el horizonte del “Espíritu Absoluto", sino que -antes bien- está en el camino a través del cual Rosenzweig 
busca liberar los contenidos de la experiencia de su sujeción al pensamiento que los integra en sus respectivos sistemas. La "superación" aludida supone un "salto" de las categorías de la filosofía a las "categorías" del universo Bíblico. El "salto" no es un "regreso" a "algo pasado", supone el esfuerzo de dar con "aquello" cuya novedad escapa a las reducciones del pensamiento (Rosenzweig, 2005, pp. 19-21, 33-34). La revelación en la Célula originaria "se pone" en la mira del pensador judío, anticipa el "salto" de los "contenidos" expuestos del primero al segundo volumen o, si se quiere mejor, de la primera a la segunda figura de $L a$ Estrella de la Redención. Si la Célula está precedida por un encuentro que es él mismo desencuentro con la filosofía, tal encuentro-desencuentro está precedido por el sentido común que impulsa.

En verdad, el lenguaje de la filosofía atraviesa la epístola, pero ello no impide que el sentido común asome, y que lo haga horadando al pensamiento - que piensa bastarse a sí mismo-, poniendo en evidencia la no coincidencia de éste consigo. El lenguaje del idealismo especulativo alemán no frena la irradiación de aquello "anterior" que empuja a lo "posterior", en la perspectiva de Rosenzweig, a la reapropiación de las palabras sentidas como propias. Sin embargo, en el camino de liberar a la experiencia de su inserción en el Todo de la filosofía, y en el medio mismo en que ésta predomina, dichas palabras de continuo se ven sofocadas por el pensamiento que incorpora en Su Sentido. La reapropiación de "toda palabra" -en el medio especulativo que impera en el tiempo del autor- no parece poderse plantear sin estar referida a algo que la explique. El predicado - siempre- obligado a superar al sujeto, con dificultad admite la facticidad prelógica de los Elementos con los que convive el sentido común. Por ello, y obrando en consecuencia con su sentido común de hombre judío, Rosenzweig rechaza la subordinación de la experiencia a una suerte de instancia que la explique o integre, resiste a la pretensión de subordinar la experiencia del otro y lo Otro al Logos de la filosofía. Consecuentemente, no sólo no rehúye enfrentar el idealismo especulativo alemán en los términos en los que éste se expresa, sino que además pone su empeño en dotar a lo que considera sus "propias palabras" de fuerza y sentido. Esto lo intenta llevar a cabo mediante un "retorno posmoderno a la fe judía premoderna" (Fackenheim, 2005, p. 49). No se trata de olvidar la puesta en cuestión de la revelación llevada a cabo por Spinoza, de musitar o elevar ensalmos ante los muros de la autoridad revelada, sino de asumir el reto de pensar en eso universal que no implica renunciar a lo particular. La revelación no 
podrá ser más entendida en el sentido en que la entiende la Tradición judía que precede a Spinoza, sino en un sentido del todo novedoso. La revelación no es judía o cristiana, sino universalmente humana. Y de lo que se trata no es de renunciar a la revelación, sino de ingresar en este saber del amor (gesto audaz de aproximación al Cantar de los cantares), por la vía que al pensador le resulta más adecuada.

La estrella de David como "estampa simbólica" ilumina desde "su antes" el presente en que la epístola se concibe. Su figura señala la no-indiferencia de $s u$ significado, indica la conciencia del autor en un universo que no abandona, en un universo en el que abunda, deseoso de mostrar "sus riquezas", ${ }^{4}$ y de cara al idealismo especulativo (en especial Hegel) que para Rosenzweig no había dejado de predominar en los ámbitos de la moral, de la política y de la cultura en general de su tiempo. La figura de la estrella de David, que irradia con luz propia al pasado de su propia “concepción”, es en las manos del hombre que la vislumbra el sano sentido común mismo que señala a su dirección. La Célula originaria es un momento en la vida de su autor. Es, en efecto, el resultado del medio en que se gestó, pero ella es solamente "un momento" de La Estrella de la Redención.

La epístola se encuentra en el orbe de la obra mayor. La redacción del embrión es anterior a la redacción de La Estrella ..., pero no es anterior a la antecedencia de esta figura que Rosenzweig experimenta y, así tampoco, al modo de conducirse del sano sentido común. La pre-originariedad del sentido común coincide con la pre-originariedad misma de La Estrella de la Redención, y, formando parte de ésta, la Célula originaria comunica sobre su gestación, lo mismo que sobre la antecedencia de "otro modo de pensar". Este "otro modo de pensar" se puede advertir a través de la epístola que -a punto de concluir sus líneaspermite distinguir una figura en la forma de triángulo (véase Figura 1), de la misma manera que en La Estrella de la Redención, en cuya configuración se muestra tanto "el entrelazamiento" de un segundo triángulo que está sobrepuesto al primero en sentido contrario, como la figura completa o final que justifica el título de la obra (véase Figura 2). En los términos, pues, de una figura que participa de la figura de estrella (véase Figura 3), pero que no es como tal estrella. Este "otro modo de pensar" supone anteceder, pero en un sentido distinto al anteceder presupuesto en la segunda figura y en la figura completa. 


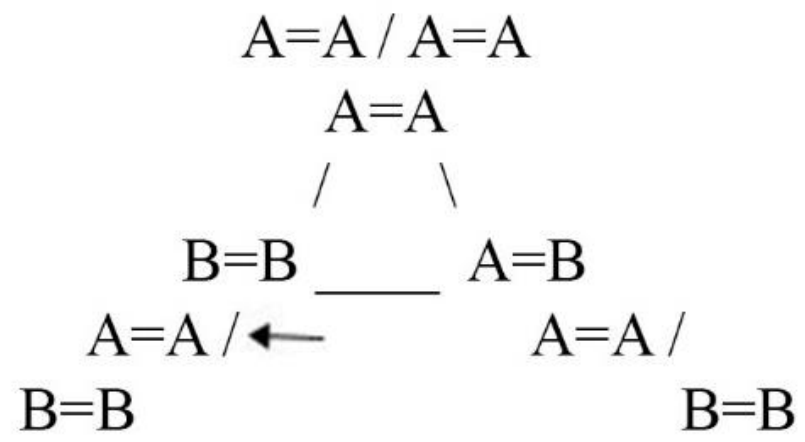

Figura 1. Es de interés - quizá- resaltar que en esta figura en que asoma un triángulo, Rosenzweig no escribe la fórmula $\mathrm{B}=\mathrm{A}$, que en el escrito es referida tres veces (Rosenzweig, 2007a, pp. 68-69). Todo un trabajo querer explicar a qué se debe que no esté incluida tal ecuación en el esquema. Toda una investigación explicar el modo en que las fórmulas $\mathrm{A}=\mathrm{A}, \mathrm{A}=\mathrm{B}, \mathrm{B}=\mathrm{B}$ y $\mathrm{B}=\mathrm{A}$ se presentan y se relacionan en la configuración de la Célula.

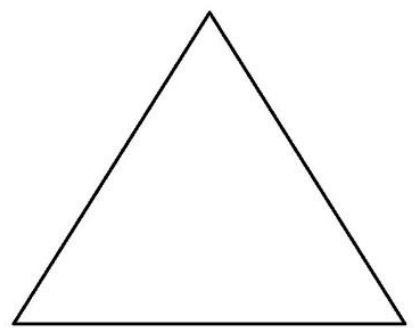

Primer figura o triángulo

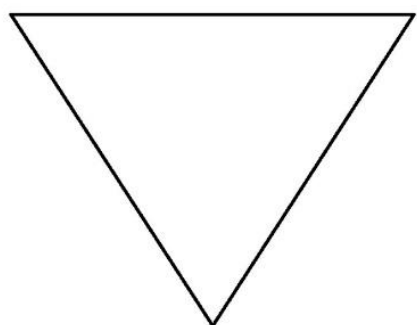

Segunda figura o triángulo

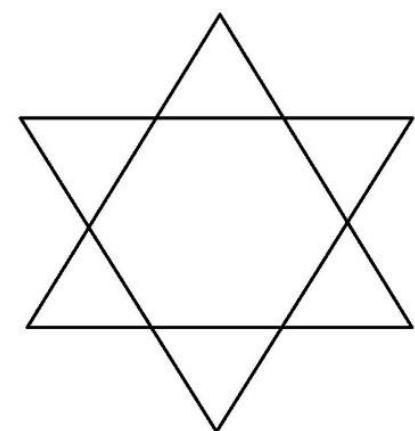

Figura completa o final

Figura 2. Figuras y/o triángulos y Figura de la Estrella 


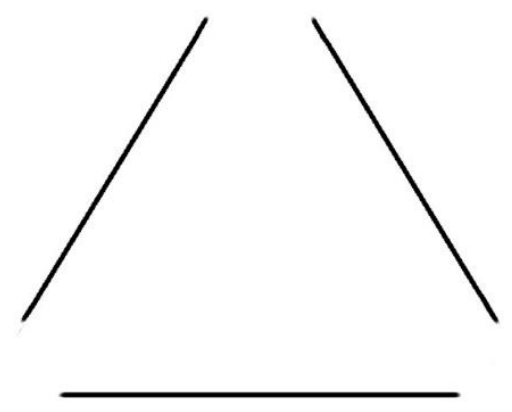

Figura 3. Configuración de las relaciones presentadas en la Figura 1

El triángulo que se alcanza a distinguir casi al término de la Célula (véase Figura 1), no es el mismo que ocupa el primer volumen de La Estrella de la Redención. En aquél está imbricado el universo que comunica al autor y aquel universo que lo provoca a buscar "sus propias palabras". En cambio, en el triángulo de La Estrella..., que corresponde al que se distingue en la Célula, el lenguaje por el que Rosenzweig apuesta exenta a éste de apelar a “sus propias palabras". El entrelazamiento de un primer triángulo que apunta hacia arriba, con uno segundo que apunta hacia abajo, se muestra en la obra central del pensador. No obstante, ello no significa que tal entrelazamiento no pueda ya -en cierto sentido- atisbarse en la misiva. Apelar a la noción de revelación en el medio de la filosofía, apuntando al deslinde de dicha noción respecto "de todo conocimiento humano", es ya permitirse comunicar por "otro modo de pensar", en verdad distinto de aquel que está sentado en la identidad entre ser y pensar.

Si el primer triángulo de La Estrella de la Redención está dedicado a Dios, Mundo y Hombre, el segundo triángulo está dedicado a la serie Creación-Revelación-Redención (véase Figura 4). La Estrella de la Redención está configurada en el entrelazamiento de ambos triángulos, y, tanto el primero como el segundo triángulo anteceden a la meditación y exposición del pensador. Por supuesto, lo mismo vale decir de la figura completa de estrella, que corresponde al tercero y/o último volumen de la obra, y que, no obstante, aquí solamente refiero de paso, pues de los “contenidos" involucrados en este volumen que centra su atención en dos "figuras históricas" de la revelación, tal como son el judaísmo y el cristianismo, no se habla en la Célula originaria. La conciencia de la precedencia de ambas figuras (del primero 
y el segundo triángulo), o, en términos menos "geométricos", la reverberación y el reflejo de estas figuras en la meditación del autor, pro-mueven a la "superación" del "horizonte conflictivo" que está presente en la Célula, empujan a la afirmación de los "contenidos vivos" del sano sentido común, que, se revela en su antecedencia y comunicando por doble partida. Esto es, tanto en los términos del universo pagano como del universo de la revelación.

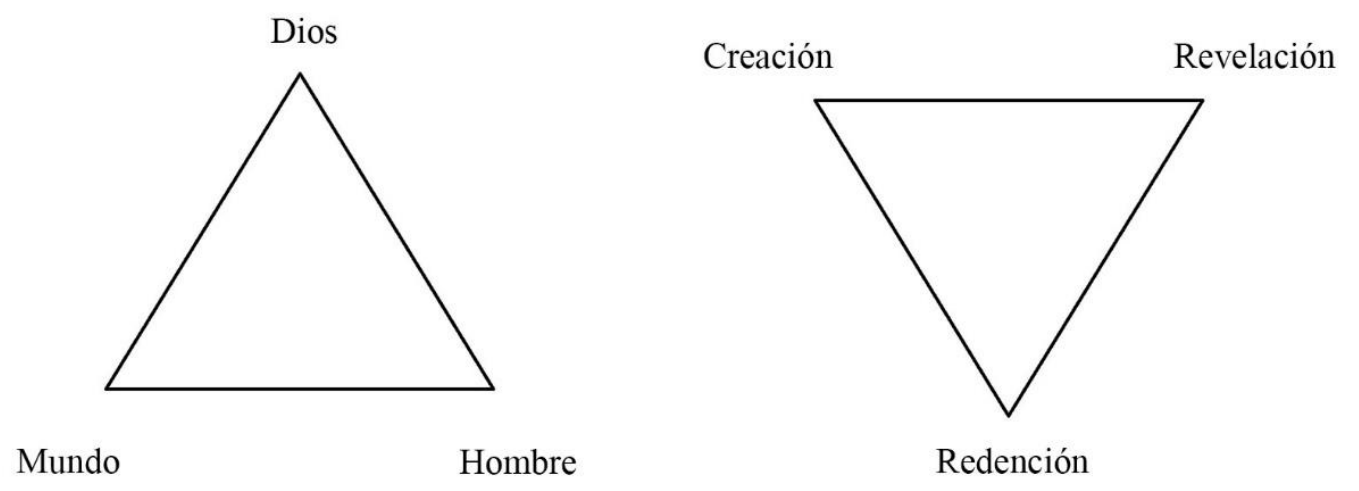

Figura 4. Triángulos que conforman la figura de la estrella

\section{El sentido común pagano y revelado en la configuración de La Estrella y la Célula}

En efecto, en el pensamiento de Franz Rosenzweig, el sentido común puede advertirse -en su anteceder y camino- lo mismo en los términos del paganismo que en los términos de la revelación. Toda la primera parte de La Estrella de la Redención, intitulada Los elementos o el perpetuo antemundo,${ }^{5}$ como afirma Lowith (2006): "contiene una filosofía del paganismo que intenta mostrar que la verdad del mundo pagano es todavía una verdad vigente, aunque no revelada" (p. 106). De acuerdo con ello, el término "pagano" en la obra de Rosenzweig no ha de comprenderse "de un modo valorativo, sino sólo descriptivo de la estructura constitutiva del pensar 'puro', previo a la contaminación o 'impureza' de la revelación bíblica" (Ruiz, 2005, p. 83). Esto es, como "un concepto que apunta a 'Atenas' previo a su encuentro -conflictivo o dialogal- con 'Jerusalén”" (p. 83). En palabras de Rosenzweig 
(2005): “el paganismo no es ni más ni menos que la verdad aunque ciertamente en forma elemental, invisible y no revelada" (p. 26).

Mientras que en la primera figura o primer triángulo de La Estrella de la Redención, Rosenzweig hace notar que Dios, Mundo y Hombre son totalidades elementales y perpetuas, y muestra que estos Elementos exceden y preceden al pensar; en la segunda figura o segundo triángulo, Rosenzweig entra en la Ruta en la que se vuelve patente aquello que excede y precede (los Elementos de la primera figura). Sin que pueda constar en esta segunda figura o triángulo, que estamos “solamente” en la órbita del mundo de la vida judía, el pensador exalta la fundamental importancia de nociones de origen bíblico. Creación, Revelación y Redención son como serie (Creación-Revelación-Redención) "una realidad” (Rosenzweig, 1997, p. 235), y esta realidad constituye la Ruta en la que el ser humano en su singularidad se abre a los "tiempos de la realidad" (Rosenzweig, 2005, pp. 31-32). Si el primer triángulo de La Estrella de la Redención se puede reflejar en el lenguaje del antemundo, atendiendo a los términos de un lenguaje que puede prestársele a tales Elementos como suyo, y que -como enseguida se verá- no es sino el lenguaje de la matemática (en el modo en el que Rosenzweig lo presenta, demasiado próximo a la filosofía); el segundo triángulo precisa para hacerse expreso de un lenguaje narrativo y gramatical.

A lo largo de toda la primera parte de La Estrella de la Redención, Franz Rosenzweig se da la tarea de mostrar a Dios, Mundo y Hombre en su aislamiento, como Elementos que a pesar de poder permutarse son impermutables. Para poder mostrar esto, el pensador judío se sirve de la matemática y sus signos que, en efecto, muestran su proximidad al lenguaje de la filosofía. Es menester una alternativa a la negación de la negación del modelo racional hegeliano, que sea capaz de "preservar la afirmación y la negación en una correlación correlativa" (Luis Costa, 2000. p. 99), y que no las funda en una síntesis englobante. Por medio de la matemática, Rosenzweig mostrará cómo es que la experiencia puede captar la diversidad sin fundarla en una totalidad englobante y que niegue la especificidad o lo específico. La diversidad podrá ser pensada como experiencia unitaria y universalmente aceptada. Y ello, sin que se disuelva bien en lo meramente diverso, o, en otro extremo, en la totalización. Partiendo del cálculo diferencial, el pensador judío "abre dos vías de la nada al algo: la vía de la afirmación de lo que no es nada y la vía de la negación de la nada. A causa 
de estos dos caminos es la matemática la guía" (Rosenzweig, 1997, p. 61) de todo este volumen. "Ella enseña a reconocer en la nada el origen del algo" (p. 61). Los Elementos se hacen presentes surgiendo de los fondos secretos de la nada, o, mejor en plural, de las nadas del saber. A fin de hacer elocuente la mudez de los Elementos, el pensador le presta a éstos un lenguaje que, si puede ser el de los Elementos es porque no es -en estricto- ningún lenguaje. Se trata de un lenguaje de antes del lenguaje, de un lenguaje de lo inaudible, y por el que cabe advertir en la nada el origen del algo (Rosenzweig, 1997, pp. 122, 151). Las fórmulas $\mathrm{A}=\mathrm{A}, \mathrm{A}=\mathrm{B}, \mathrm{B}=\mathrm{B}$ y $\mathrm{B}=\mathrm{A}$, que laten - con acentos distintos - a lo largo del embrión, y que encuentran su formulación definitiva en el primer volumen de la obra capital del pensador, expresan dicho lenguaje.

Ahora bien, es frente al lenguaje de lo inaudible que habrán de hacerse audibles las palabras reales, no el lenguaje de antes del lenguaje sino el lenguaje real (Rosenzweig, 1997, pp. 151-153, 169). Al lenguaje de la matemática, que se dispone a ser articulado en el sentido de la filosofía, y que está "incluido" en la primera parte de la obra, sigue un lenguaje narrativo y gramatical, expuesto de manera fundamental en el segundo volumen, cuyos tres libros apuntan al pasado, al presente y al futuro, a la Creación, a la Revelación y a la Redención, respectivamente (Rosenzweig, 1997, pp. 193, 195).

Tanto en la primera como en la segunda figura de La Estrella de la Redención, el sano sentido común puede advertirse comunicando. En el primer caso, en los términos elementales y perpetuos del universo pagano; en el segundo caso, en los términos de un lenguaje narrativo atento al universo de la revelación. Esto último de ningún modo quiere decir que "estar atento" a la revelación suponga de modo necesario "ser judío" o "cristiano" (ser lo uno o lo otro no es una "condición necesaria" para la segunda figura de La Estrella de la Redención). "Estar atento" a la revelación aquí significa "dar por sentada" la fractura del connatus serpensar, asunto fundamental para "la autoconciencia absoluta" del "último cerebro pagano" que es Hegel, según Rosenzweig (2007a, p. 58). "Estar atento" significa aceptar la singularidad de un pensar experiencial, que nombra sus nombres no en un sentido atemporal, sino ante todo y sobre todo de acuerdo a su temporalidad (Rosenzweig, 2005, p. 31). En tanto que la figura de estrella antecede al embrión que apunta hacia ella, coincide con la plenitud del sentido común judío, pero, en tanto que prevalecen los contenidos del primer triángulo (Dios, Mundo y Hombre), estamos ante el sentido común tal como éste se presenta en el 
pensar pagano. El sentido común puede mostrarse en los términos de ambos universos. Y, por ello mismo, también, como anteceder y como marcha que acompaña. Aquello que antecede a la epístola la provoca, el conflicto entre filosofía y revelación germina, estimula a la "comprensión" de "los contenidos" con que convive el paganismo y la revelación, sin que ello signifique que estos "contenidos" sean "resultados" de la "comprensión". Aquello que acompaña en la exposición de la Célula, es el mundo vivo de los universos que la integran, irrumpiendo y empujando a la afirmación de su saber. El sentido común antecede y pro-mueve. Y, por cierto, sin que ello pueda en algún sentido significar paralizarse en "un pensamiento", tal y como llegará a suceder con el advenimiento del paganismo histórico. ${ }^{6}$ Aquel "otro modo de pensar" al que he hecho referencia -insisto- no es sino el sentido común, y puede advertirse lo mismo en la Célula originaria que en la configuración de La Estrella de la Redención.

Tanto en La Estrella de la Redención como en la Célula originaria es posible advertir el modo en que el sano entendimiento late y se va abriendo paso en medio de la especulación que lo considera como un saber subordinado, en una "estancia" o "lugar" "inferior" al del pensamiento sentado en la simultaneidad del ser y pensar. Sólo que, en el caso de la primera, dicho modo de latir y de abrirse paso sólo parece así poder considerarse en el volumen primero o primer triángulo, en la mostración de la indefensión y el aislamiento de Dios, Mundo y Hombre, Elementos perpetuos y mudos dispuestos a su nombramiento en el universo pagano, y que constituyen el antemundo del concepto (Rosenzweig, 1997, pp. 204, 311, 351-352). Para después hacerse notar -tomando distancia respecto a esto primero- en el segundo volumen o segundo triángulo, en el que el sentido común se hace manifiesto en los términos de un lenguaje atento a la revelación o, para ser más precisos, a la revelación de la serie Creación-Revelación-Redención. Tal es la Ruta a través de la que el autor describe aquello en lo que creemos con las palabras en las que confiamos, y en la que se hace presente el milagro de la novedad. Mientras que el volumen de los Elementos es expuesto sin referencia alguna a la revelación, el volumen dedicado a la Ruta pone en el centro a la Revelación, corazón de la obra.

Mientras en el volumen de los Elementos el pensamiento se encuentra con Dios, el Mundo y el Hombre, jugándosela entre la aceptación de sus facticidades o de la integración 
de éstas en el Todo de la filosofía, el volumen de la Ruta hace manifiesto el movimiento de flujo en que tales Elementos abandonan su ser oculto y perpetuo, en el que abandonan el antemundo del concepto para hacerse patentes en el mundo como algo siempre renovado. El sentido común pagano abraza los Elementos fácticos. Esto se ve reflejado en la madurez del paganismo, en "el Dios vivo del mito, el mundo plástico del arte, el hombre heroico de la tragedia" (Rosenzweig, 1997, p. 131). El sentido común judío también abraza tales Elementos, pero al tiempo de hacerlo resiste a reducirlos o permutarlos entre sí. El antemundo de los Elementos, su ocultamiento perpetuo, encuentra en la Ruta el testimonio de la revelación (Rosenzweig, 2007a, pp. 58, 60). Si en el primer volumen cabe un pensamiento capaz de permutar los Elementos, y cabe también la imposibilidad definitiva de reducirlos entre sí, el segundo volumen se abre a un pensamiento que acepta la incursión de Dios en la vida del hombre o, mejor - para los fines de este trabajo- a un universo abierto a la experiencia relacional de lo humano, lo divino y lo mundano.

Lo que en La Estrella de la Redención está separado en sus tres volúmenes, en la Célula originaria está condensado. La revelación es evocada en el interior de una época en cuyo tiempo el paganismo histórico parece haber triunfado, delante de las autoconciencias de Hegel y de Goethe (Rosenzweig, 2007a, p. 58), de la relación en la que el ser humano tiene al absoluto (p. 60). Necesario será para Rosenzweig entrar al debate entre lo racional y lo extrarracional. Mundo pagano y mundo revelado comparten sentido común, y el lugar asignado al Logos, capaz de integrar a la revelación, define el punto de vista por medido del que, el ser humano singular puede evidenciar o poner de manifiesto el modo en que lo extrarracional escapa a lo racional, o por el que lo extrarracional se pone al "servicio" de lo último.

Lo condensado en las páginas de la Célula originaria, es ampliado y dividido en $L a$ Estrella de la Redención. El pensamiento que busca en aquélla poner al descubierto "algo importante" (Rosenzweig, 2007a, p. 56), y que de continuo parece sofocarse ante el idealismo especulativo que alcanza al pensador, advierte en ésta una división. El universo de la filosofía encuentra su lugar en el primer triángulo, mientras que el universo de la revelación tiende a ocupar su lugar a partir del segundo triángulo, y no en el modo en que lo hace en el tercer volumen de la obra, pues mientras que en este tercer volumen Rosenzweig se las ve con las figuras históricas de la revelación (el judaísmo y el cristianismo), en el segundo triángulo (o 
volumen) -como atrás lo he referido- trata sólo de la Ruta por al que se vuelve patente lo oculto, los Elementos de la primera figura. La primera y la segunda figura -en el interior de la epístola- se encuentran compenetradas, implican la conciencia del autor en una disputa inevitable (en la que él mismo se encuentra envuelto), en cuyo terreno se alerta -más allá de la discusión con la filosofía- un anteceder que ha sido testimoniado en la vida de millones de seres humanos, tanto en los términos del universo pagano como del universo de la revelación. La superposición de los triángulos que prestan figura a La Estrella de la Redención, supone el "encuentro" entre estos universos. Ambos universos confían en sus respectivas experiencias. Pero, según Rosenzweig, aquél -llegado el momento- tiende a alejarse de dicha confianza. Afanándose por resolver la realidad de "lo que es", inaugura el camino por cuyos pasos "el culto por el concepto" sustituye la experiencia humana y la confianza en ésta, hasta el punto de que nada pueda escapar a esa manera de ser de la filosofía que insiste en decir "todo es". Al paganismo creacional sigue el paganismo histórico.

Y es que, en efecto, si el paganismo creacional es elemental y está en el seno de lo visible y de lo invisible, secreto y oculto más no revelado, el paganismo histórico asume que puede explicar el sentido de todo, lo mismo de lo visible y de lo invisible. Y esto, hasta el punto de que no sea él mismo secreto y oculto, sino "eso" mismo que "es" el "ser que revela". Erigiéndose como la verdad de la totalidad, el paganismo histórico abandona "su ser elemental", "visibiliza la invisibilidad" (suya y de cuanto lo rodea y/o atraviesa), hasta el punto de considerarse "figura fundamental". Tal es la manera en que este paganismo se consolida como "forma rígida", que ajeno a la "realidad efectiva", tiende a fungir como límite y centro de todo conocimiento (Rosenzweig, 2005, pp. 26, 38-39). Parafraseando a Rosenzweig dice Ruiz (2005):

Se convierte en mentira siempre que quiere ser no elemental sino el todo, no invisible sino figura, no secreto sino revelación [aludiendo a Hegel, como cifra y símbolo de la filosofía occidental]. Pero como elemento y secreto habita perpetuamente en el todo, en lo invisible y en lo revelado. (p. 98)

Lo expuesto en la meditación de la Célula originaria, es sólo una parte de lo que se encuentra en la configuración de La Estrella de la Redención. Y si digo que es sólo una parte de La 
Estrella, es porque asumo -como ya he abundado-que lo expresado en la Célula es tan sólo una parte de la primera. Ello se puede vislumbrar -como ya lo anticipé- en la figura que se distingue casi al término de la epístola, no en una estrella sino en un triángulo (la figura de estrella queda incompleta), y en uno -por cierto- en que Dios, Mundo y Hombre son pensados en una tensión que se las juega entre el sentido filosófico implicado en tales Elementos y la experiencia del ser humano que, con sentido común, con ellos convive y los acepta.

\section{De la disputa de la Célula y el sano sentido común para Hegel y Rosenzweig}

Que no quepa duda, la Célula originaria es embrión gestado en el contacto de los universos que la anteceden, se dibuja en el orbe del pensamiento como resultado de un pensar atento a las respuestas humanas. Pero de cara a un pensamiento para el que el pensar y lo pensado son simultáneos, y que cimenta sus pasos en la intemporalidad de sus principios, apela al "derecho legítimo" del ser humano a expresarse en sus "propias palabras". La referencia a la revelación, tanto al principio como a lo largo de la exposición de la misiva no debe extrañar. Este término de origen bíblico, puesto en la boca del hombre que lo nombra, no está limitado al de su resolución en las coordenadas de la filosofía: presupone la atención y la conciencia del autor en una tradición que comunica, y que "afirma la peculiaridad irreductible del judaísmo, su negativa en nombre de su vocación propia, a dejarse absorber por la civilización circundante" (Mosès, 1997, p. 35).

A través de la Célula originaria, la tradición de la filosofía y la tradición judía se entrelazan, se enfrentan y separan, mostrando el temple de un pensador que no rehúye tomar posición delante de las tendencias y de las corrientes de pensamiento que predominan en su tiempo y cuyas consecuencias culturales, morales, políticas y sociales vivimos en el nuestro. La Célula no es sino el primer atisbo de la meditación de un hombre que, resistiendo a la fuerza del idealismo especulativo, barrunta en el seno de éste una fractura irrecuperable, en cuya rasgadura habrá de advertirse a la experiencia liberada de su sumisión al pensamiento del Todo (Kuri, 2018b). Expresión viva de la lucha que Rosenzweig sostiene en el terreno del entendimiento, esta epístola constituye el primer paso que su autor da en la búsqueda de conseguir romper con los excesos implicados en una filosofía que, partiendo de la unidad entre ser y pensar, parece asumir en Su Sentido la totalidad de las experiencias de los seres 
humanos. Lo que antecede abraza la experiencia del hombre singular, que medita trenzado de la totalidad que lo envuelve, siendo él mismo conexión entre los universos de la filosofía y de la tradición judía. La disputa con el idealismo especulativo en la Célula originaria, refleja la travesía del ser humano singular que no rehúye enfrentar a la filosofía en sus propios términos, haciendo filosofía "a pesar de la filosofía". De cara a cuanto confronta, el pensador judío apunta a la antecedencia de "otro modo de pensar" configurado en La Estrella de la Redención, que como figura completa de "su pensamiento" aplaude el derecho legítimo de los seres humanos a confiar en sus propias palabras y en los contenidos de sus experiencias.

En contra de la estrechez que Hegel parece asignarle al sano sentido común cuando en el prólogo a la Fenomenología del espíritu dice -señalando a éste- que: "la figuración no razonable de verdades establecidas, sobre las que quien las posee cree que no hace falta volver, sino que basta con tomarlas a la base y expresarlas y enjuiciar y condenar a base de ellas" (Hegel, 2008, p. 44), haciendo notar que, es "especialmente necesario que la filosofía se convierta en una actividad seria" (p. 44), el sano sentido común en Franz Rosenzweig apunta a la singular universalidad de un saber. Saber que no sólo no tiende a la "figuración no razonable de verdades establecidas", a la apoteosis de algo que dándose por sentado permita erigir un juicio o una construcción especulativa, capaz de justificarse en la credulidad de algo que se posee, sino que no tiende - de hecho-ni siquiera a la convicción de la posesión de "una verdad" que pueda pretenderse absoluta, capaz de ser el sino mismo de lo que no coincide consigo, la fuente manantial que recoge en su origen las realidades diversas, hasta resolverlas en un modo de ser específico. El sano entendimiento o sano sentido común en Franz Rosenzweig no considera la verdad como una esencia o algo intemporal, como si se tratase de algo posible en virtud de un mundo o realidad en sí que lo permite; no considera que lo que sabe sea una prueba hasta el punto de poder ponerse a la base de todo, permitiendo enjuiciar y condenar cuanto no le parezca. Y ello, porque este saber ni se basta a sí mismo, ni se concibe tampoco condenando desde ninguno de sus sentidos. Sin duda, se trata de una "actividad" tan "seria" como aquella a la que ha de aspirar la filosofía a la que Hegel invita, pero ello no porque se disponga a ser sujeto de pruebas, y deba entonces tener el "rigor necesario" a que ha de aspirar el conocimiento pretendido "más alto" y "más puro", 
sino porque su funcionamiento merece el trato o, si se quiere mejor, la seriedad misma con que la filosofía se regocija consigo.

Lejos de la convicción de que cuando el sano sentido común pretende hacer filosofía no la hace sino en tanto que un "filosofar natural", de manera tal que cuando el pensamiento “discurre por el cauce del sano sentido común" no hace sino sólo producir "una retórica de verdades triviales" (Hegel, 2008, p. 45), pues el pretendido "buen sentido" sólo "apela al sentimiento, a su oráculo interior, rompiendo con cuantos no coinciden con él”, y apuesta a pisotear "la raíz de la humanidad", revelándose como algo "antihumano", "animal", por querer mantenerse en el "terreno del sentimiento y comunicarse solamente por éste" (p. 46). El autor de La Estrella de la Redención, apunta a la ruptura del sano entendimiento respecto a todo supuesto "filosofar natural", poniendo su esfuerzo en mostrar que el sano sentido común no se circunscribe a un modo de ser específico, que, por ende, no puede pretender convencer, provocar o persuadir a algún tipo de resultado, así como tampoco pretender tener su motivación principal en una suerte de sentimiento emotivo capaz de querer convencer o rechazar sentado en sus afecciones. Y ello, ante todo, porque en lo absoluto se trata de un pensamiento pretendido esencial, pues su "naturaleza" no se define por "una respuesta”, sino por la dinamicidad misma que tiene consigo la vida. Si en Hegel (2008) "a los verdaderos pensamientos y a la penetración científica sólo puede llegarse mediante la labor del concepto" (p. 46), y es solamente el concepto el que:

Puede producir la universalidad del saber, que no es ni indeterminabilidad y la pobreza corrientes del sentido común, sino un conocimiento cultivado y cabal... la verdad que ha alcanzado ya la madurez de su forma peculiar y susceptible de convertirse en patrimonio de toda razón autoconsciente (Hegel, 2008, p. 46).

En Rosenzweig, los "verdaderos pensamientos" y "la penetración científica” no son sino sólo corolarios directos de una manera de pensar que vindica "su ser" en el orbe de un pensamiento que parte a su búsqueda en la omisión o la anulación de todo supuesto, amparando "su ser más propio" en la simultaneidad del pensar y lo pensado. El sano sentido común en Franz Rosenzweig le disputa la preeminencia al culto por el concepto. El sano entendimiento acepta el acontecimiento, no sujeta el aparecer en "la labor del concepto", ni 
en nada que quiera “ponerse en su lugar". El acontecimiento tiene consigo su "antes”, y éste es respecto lo que está “después”, lo mismo depósito presto a ser tematizado que apertura inasumible a un "modo de ser". El saber del sentido común no es una suerte de “indeterminabilidad”, su "singularidad”, su “peculiaridad” y “concreción” están en el mundo de la vida. Tal es su universalidad y riqueza, que no precisa ser un "conocimiento cultivado y cabal", así como tampoco pretender alcanzar la "madurez" de una "forma peculiar", capaz de "convertirse en patrimonio de toda razón autoconsciente". El sano sentido común es “patrimonio humano", pero en lo absoluto "patrimonio de toda razón autoconsciente". Y esto en lo absoluto es un defecto. La captación del "ser" del sentido común, se hace manifiesta en la exposición de la puesta en marcha de su comportamiento, en cuyos pasos se muestra tanto su precedencia como de los supuestos que lo acompañan.

En contra del pensamiento que se inclina a resolver la verdad de lo real en la intemporalidad de los caminos del ser, de la esencia o la existencia, del objeto y del sujeto, Franz Rosenzweig hace explícito un pensamiento para el que la verdad es testimonio. Se trata de un pensar experiencial que afirma la verdad como verdad para alguien. En lo absoluto se trata del revelarse de la verdad de sí misma, del encarnarse la verdad en el Espíritu Absoluto. La verdad de lo real excede al "sujeto cognoscente", y es una mezcla de satisfacción y de tragedia "conocer" en la "labor del concepto". No saber en el saber del sano entendimiento.

\section{La figura de estrella}

La elección de la estrella de David como figura a través de la cual Franz Rosenzweig expone su pensamiento no es fortuita, presupone la afinidad del autor con el universo del cual se considera partícipe, señala con antelación la intención de plantear un pensar cuyo eje interpretativo tiene su origen no en los griegos sino en la Biblia. La figura presupone la conciencia de algo anterior al pensador, de algo en lo que él penetra a partir de su singularidad experiencial. Tras haber estado perdido por los caminos del pensamiento europeo, de haber estado al borde de la conversión al cristianismo y haber participado en la guerra total (Mosès, 1997, pp. 32-52). ¿Significa esto inscripción o resolución anticipada de lo problemático, respuesta previa a toda pregunta antes de hacerla? La elección de la figura frente a un horizonte marcado por Hegel y por Goethe, por las "autoconciencias absolutas de ambos" 
(Rosenzweig, 2007a, p. 58) no es ingenua, anticipa el rechazo que dicha "elección" puede suscitar. La figura presupone la aceptación de un universo que irradia, que comunica. No significa que establecidas estén las premisas y las conclusiones, que la estructuración de la obra conduzca a la comprensión "lógica" de la figura. Estamos ante una "figura construida geométricamente pero ella misma ajena a la geometría: no una figura geométrica, sino una figura" (Rosenzweig, 1997, p. 309). Ésta permite presentir "el lugar" del que surgió. Pero, el presentir no supone la comprensión, mucho menos la conclusión. En la elección de la figura (que no es arbitraria) está superada la propia elección, que sólo puede ser tal en virtud del sentido común que señala hacia su dirección. Obrando en conformidad con el judaísmo, Franz Rosenzweig apunta a la universalidad de "su pensamiento". No obstante, tan pronto ingresa uno a La Estrella y de inmediato se nota que lo que ahí está presente no es sólo el judaísmo, que lo que está involucrado rebasa con creces la intención de una lectura que tienda a reducirlo a ser sólo tal. Lo con-tenido en los "trazos" que dan forma a la figura rebasa a éstos, lo universal irradia sobreponiéndose a toda circunscripción; la pre-comprensión de Dios, Mundo y Hombre, exceden la vía de una "lógica" comprometida consigo. La figura es sólo figura, y es sólo entrando en ella como puede advertirse su resplandor. El título de la obra pone sobre el plano del pensamiento de la época una figura cuyo sentido no puede hacerse perceptible sino hasta incurrir en sus páginas. La figura es judía, y, sin embargo, en lo absoluto decide la pertenencia: el "ser un libro judío". Tan no lo decide, que el pensador prefiere considerar a su obra "meramente como un sistema de filosofía" (Rosenzweig, 2005, pp. 14-15).

En la elección de la figura, está, pues, reflejada la puesta en escena del sentido común de nuestro autor. Sin embargo, el "elemento" judío es sólo perceptible en el título. Pues, sin duda, no se trata sólo de un "libro judío". La Estrella de la Redención insufla el pensamiento judío, pero no más de lo que puede insuflar el pensar pagano y cristiano. En la sola figura se advierte la "faz" de un viraje que invita e interroga a la vez, incitando a incursionar en las "líneas" o "trazos" que la constituyen, sea para probar si es que estamos ante la vuelta de un viejo o nuevo horizonte, o para tener en cuenta sobre el plano del pensamiento que impera la "estampa simbólica" de un universo que no por no verse no está. Interés y desinterés colindan en el cariz de un "símbolo" que indica incluso en la indiferencia. La figura prefigura, representa anticipadamente en su "ponerse a la vista" la anterioridad de lo en ella avistado. 
La figura que apunta al título de la obra en la portada es más que sólo su portada, es puerta a un camino imponente, enigmático. La Estrella de la Redención desborda la pretensión de ser absolutamente comprendida. (Y ello, porque no se trata sólo del "producto reflexivo" de un hombre que, como tal, puede tener aciertos o erratas, sino también de la "voz viva" e interminable del comentario exegético). Sus claroscuros -repletos- de simas y cimas, no se agotan en las líneas que la configuran. El resplandor se avista en el transcurrir de sus páginas, en la marcha de su lectura. La figura no es fruto de una invención, tampoco lo es lo que en ella está contenido ( en juego no sólo de la anterioridad presupuesta en la que Rosenzweig se sitúa, y, a partir de la que se decide hacer eco de lo que antecede, sino también un resplandecer que rebasa al ser humano singular, trayendo la iluminación de los rayos al presente de la vida en que festeja y da gracias.

Obra de vida que fulmina por su potencia la premura de la impaciencia que quiere resolver, convencerse mediata o inmediatamente del error, de la falla, de la insuficiencia; amparándose del gusto o los tonos del tiempo, de la erudición incansable y la lectura insaciable; La Estrella de la Redención regala al lector preocupado por el ofuscamiento de sus palabras, la oportunidad de ver hacia fuera, al camino de la vida más allá del libro.

Tras haber publicado La Estrella de la Redención, Rosenzweig (2007b) declara que “el nuevo libro no deja de ser... un libro" (p. 87). Lo que sigue a su obra mayúscula es, como lo declara: "la pequeña -y a menudo minúscula- 'exigencia del día'.... eso, y ya no escribir libros" (p.87). Estamos ante un conocimiento que no se considera "un fin en sí mismo", sino ante todo "un servicio" (p.87). Y esto, no entendido en el sentido de un servicio para las tendencias, cuestión ajena a un pensamiento que quiere servir al ser humano. No se trata de paráfrasis alguna del humanismo ilustrado, tampoco de un símil de la modernidad. Siguiendo al Eclesiastés, Franz Rosenzweig sabe que de escribir libros no se termina, que los libros no son la vida sino una parte de la misma.

\section{Consideraciones finales}

A través de este trabajo he abundado en la precedencia que el sentido común y La Estrella de la Redención tienen respecto a la redacción de la Célula originaria, ello lo he intentado 
apuntalar yendo de adelante hacia atrás, de los prolegómenos al "origen" de la obra capital, de la explicitación de las figuras de La Estrella de la Redención al "origen" de ésta y, de cara a la epístola, enfatizando que ésta está precedida por la tradición de la filosofía y la tradición judía (introducción y primer apartado). Todo esto procuré relacionarlo a una sucinta disgregación gramatical del título de la carta que ha tenido -al menos- tres funciones específicas (explicitadas a lo largo de la introducción y del primer apartado), a saber: vislumbrar lo previamente expuesto centrado en el título; señalar a "aquello" que antecede a la misiva; más en general, resaltar un abordaje de estudio empeñado en mostrar cómo es que el sentido común se hace presente desde el "origen" de la obra central. "Aquello" que comunica a la Célula no es resultado de un pensar solitario, solipsista o encerrado en sí mismo. Todo lo contrario. Si la Célula puede ser vista como embrión es porque nace de algo y no -simplemente- porque es origen de algo (segundo apartado).

El "origen" de la "Célula" no es sino el de un embrión y, como tal, es imposible sin la relación o, digámoslo así, sin la "maternidad" y/o la "paternidad" de la filosofía y el judaísmo. Esta afirmación no es insignificante desde el punto estratégico del escrito que presento, pues pone en perspectiva la carta que no se ve simplemente como comienzo. El encuentro -o desencuentro- de la filosofía con el judaísmo, la puesta en cuestión de la subjetividad de Rosenzweig, y el presentimiento de haber conseguido algo importante empujan a la redacción del embrión. Frente a la filosofía del idealismo especulativo alemán que afirma la identidad entre ser y pensar, la subsunción de la vida en el concepto y, en general, de todas aquellas filosofía que indica todo "lo que es" y "no es", la exacerbación de un planteo que desde su "inicio" tiende a la ruptura del pensamiento pensante: "otro modo de pensar" que afirma lo singular, que no refiere "su ser" al Todo pensable sino al mundo de la vida.

Efectivamente, en el "origen" de La Estrella de la Redención asoma el mundo vivo de Franz Rosenzweig. Y este mundo vivo no se presenta en la disputa suscitada en el embrión como algo infecundo, sino como un origen originario que promueve a la superación de lo que en éste está problematizado. Este origen originario antecede el "origen" en que nace la Célula, y ello, hasta el grado de comunicarla y permitir destensar lo en ella en tensión. El "sano sentido común" precede al pensador, y también lo hace la estrella de David, que como "estampa simbólica" de "su pensamiento" es vislumbrada en los términos de La Estrella de 
la Redención. Si del embrión puede decirse que es "resultado" del enfrentamiento entre la tradición de la filosofía y la tradición judía, no puede decirse lo mismo de la obra mayor. Y es que La Estrella de la Redención expresan en su figura una anterioridad que precede no sólo al ser humano singular -que es Rosenzweig-, sino también a la filosofía de la identidad. La figura de la estrella y de sus triángulos, de los “contenidos" implicado en ambos, desbordan a la Célula originaria (a la disputa en medio de la cual el filósofo busca expresar "su pensamiento"), pero, también por esto mismo es factible decir que pueden ayudar a elucidarla (segundo apartado).

En la marcha del trabajo que presento hay un giro de la Célula y de lo implicado en su concepción a La Estrella de la Redención (del segundo al tercer apartado). Este giro está justificado tanto por lo que este escrito - desde el principio- busca poner de manifiesto, como por el título de la misiva y de los contenidos en ésta presupuestos. El punto de Arquímedes filosófico de Franz Rosenzweig, que para éste no es otro que la revelación, impulsa a la redacción del embrión, y en el esfuerzo por pensar este "término" bíblico asoma "otro modo de pensar". Este "otro modo de pensar" que en el texto ha sido referido como "sano sentido común", no es para Rosenzweig sino un nuevo pensamiento que se aparta del pensamiento pensante, un pensamiento hablante en cuyo comportamiento se puede notar un pensar abierto a la exacerbación de sentido y a las no-coincidencias. En el lugar de la asimilación, la disimilación (Mosès, 1997, pp. 29-48): el esmero puesto para mostrar una fracturara irrecuperable en el seno de la identidad de ser y pensar (Kuri, 2018b), y atendiendo lo mismo a las formulaciones del idealismo especulativo alemán que a las palabras siempre presentes en el mundo vivo del judaísmo. ${ }^{8}$ Frente al "hambre de formas" (Rosenzweig, 2007b, p. 86), el mundo de la experiencia de la que abreva el autor: el asomo novedoso de la revelación; no algo fundado en uno de los Elementos sino en la Ruta (tercer apartado).

Sin duda, lo divino, lo mundano y lo humano han sido referidos, conducidos por la filosofía han sido subsumidos; pero, "logro" de la excedencia no es la subsunción, sino acaso la interpelación. La Creación, la Revelación y la Redención son como Ruta “el lugar” por el que camina la experiencia judía, que mira la distancia entre las cosas divinas, mundanas y humanas. Y propio de esta tradición - desde la óptica de Franz Rosenzweig (1997)- no es permutar tales cosas, pues "todas las cosas son testimonios" (p. 206). Y ello, hasta el punto 
de que Dios mismo sólo por testimonio pueda ser tal (p. 216). El testimonio es singular (p. 406), y el lenguaje describe la Ruta en la que asoman los Elementos poniéndose a las manos de aquellos que los nombran (p. 195).

En efecto, el mundo de la experiencia no puede ser agotado en uno de los Elementos, esto es, en una de las puntas del triángulo primero de La Estrella de la Redención. Sin embargo, qué duda cabe de que ello ha sucedió a través de la historia del pensamiento, y qué duda cabe también de que ello sucedió sin que el sentido común dejara de confiar. Lo que está "antes" de la Célula se presta a, es algo pre-sistemático y por ello mismo capaz de prestarse a ser sistematizado. ¿Cabe sostener en La Estrella de la Redención cierta presistematicidad capaz de ser sistematizada? Hasta cierto punto, ¿no es esto algo de lo que se ha puesto de manifiesto en el presente trabajo? No hay que olvidar que Rosenzweig (2005) se refiere a "su pensamiento" como un sistema de filosofía (p. 15). No es inaudito o absurdo haber querido mostrar desde el "origen" de La Estrella de la Redención "otro origen que la dirige". Haciendo caso a la indicación de que estamos ante un pensamiento no inventado sino siempre enseñado por el sentido común, no parece tampoco inaudito afirmar que los Elementos Dios, Mundo y Hombre en su pre-sistematicidad se presten a, como elementos antemundanos perpetuos y dispuestos a su nombramiento, que, pues, están "a las manos" del mundo de la experiencia y no sólo como Todos envolventes de todo lo "otro". Frente a la tentativa de una razón puramente lógica y replegada en sí misma, Franz Rosenzweig propone una razón dialógica y abierta a la vida (cuarto y quinto apartado).

El ser humano singular puede confiar, y puede también avistar aquello en que confía. La exacerbación del sentido del mundo de la vida germina: los Elementos Dios, Mundo y Hombre pueden nombrarse y reducirse entre sí; pero, sentido común judío -de acuerdo a lo que Franz Rosenzweig estima- es también aceptar una distancia infinita entre las cosas divinas y mundanas, entre las cosas divinas y humanas. Ese "otro modo de pensar" -о nиevo pensamiento- que considero de la mano del autor judío como sano sentido común no deja de comunicar, e inestimable es "aquello" que desborda, aquello que impugna el pensamiento entregado a su propia altura. 


\section{Aportes del trabajo}

La tesis extraída de Franz Rosenzweig en el sentido de lo que "su pensamiento" enseña no es sino lo que el sano entendimiento humano siempre ha pensado, y que, tanto en El libro del sentido común sano y enfermo como en El nuevo pensamiento se afirma señalando a La Estrella de la Redención, no es una tesis sencilla de sostener. Generalmente, a Rosenzweig se le señala como el iniciador del nuevo pensamiento, al que él se refiere como sano sentido común. Sin embargo, no es común encontrar estudios en los que se pretenda profundizar en lo dicho, mucho menos si esto se pretende mostrar desde la "Célula originaria" de la estrella de la redención. De acuerdo con esto, considero que este trabajo puede servir como una entrada a la obra del autor, asimismo, inspirar en el lector apertura hacia una forma de abordar la misiva y -en general- este pensamiento. Que la epístola cabe en el orbe de la obra mayor no es una obviedad, algo dado por sentado para aquel que se interesa por Rosenzweig. Tampoco es una obviedad considerar que el sentido común comunica a la Célula originaria, que coincide con La Estrella de la Redención y que, tanto aquélla como ésta son preoriginarias al embrión. Más plausible es admitir que en la redacción de la carta son presentes tanto la filosofía como el judaísmo, que es posible resaltar un exceso de sentido implicado en el "origen" mismo de la redacción de La Estrella de la Redención, advertir que de cara a esto medita el pensador. Sin embargo, se trate de obviedades -o no-, cualquiera que se interés en el pensamiento de Franz Rosenzweig y, de manera concreta, por comprender lo expresado en su carta (relacionándola con la obra magna y el sentido común), se dará cuenta del exiguo abordaje de lo que en este escrito se ha intentado.

Los estudios sobre Franz Rosenzweig son escasos, y no creo equivocarme en sostener que en el mundo hispanoparlante los que hacen referencia al papel y la función del sentido común en la Célula originaria son prácticamente nulos. Generalmente Rosenzweig suele ser reconocido como el iniciador del nuevo pensamiento, que no es otro-como él mismo lo hace notar- que el del "sano sentido común", sin embargo, cuando uno acomete la tarea de entrever lo dicho pronto asoma la impresión de que no hay una línea de unión entre dicha afirmación y su obra central, mucho menos, con el "origen” de ésta (la Célula). Por esto mismo, considero que algo importante que puede entreverse desde este abordaje (que insisto solamente enmarca mi investigación), es el esfuerzo de presentar una línea de unión de las 
tres principales obras del autor, a saber: La Estrella de la Redención, El libro del sentido común sano y enfermo y El nuevo pensamiento. Y ello, yendo de lo que Rosenzweig comprende por sano sentido común al “origen” de La Estrella de la Redención.

En concreto -y para finalizar- quisiera subrayar algunos de los temas en los que considero puede aportar algo este trabajo: destensar la lectura de la epístola atendiendo a lo que Franz Rosenzweig dice sobre "su pensamiento" en los prolegómenos de la obra magna; mostrar el embrión de La Estrella de la Redención como un momento de la vida y de la obra de Rosenzweig y no solamente como el principio de ésta; advertir en las figuras de triángulos -que conforman a La Estrella de la Redención-aquellos contenidos que ayudan a destrabar lo implicado y en tensión en el embrión; relacionar el triángulo de los Elementos y el triángulo de la Ruta con lo que el pensador entiende por sentido común; y, en fin, señalar a la peculiaridad de un saber que - de cara a Hegel- afirma su derecho a expresarse en sus propios palabras y, de acuerdo a una figura que no es sólo no-indiferente sino que, además, refleja no sólo la vida especulativa del autor judío, sino de un pensamiento dialógico de la vida y para la vida.

\section{Notas de contenido}

${ }^{1}$ A lo largo de este trabajo el lector podrá darse cuenta de que con insistencia pongo entre comillas la proposición "su pensamiento", ello no es baladí, resalto así el exceso de sentido presupuesto en la afirmación hecha por el mismo Franz Rosenzweig (2005) en el sentido de que lo que su pensamiento sostiene no imagina "haberlo inventado", ni tampoco ser él "el único en enseñarlo", sino que, antes bien, "el sano entendimiento siempre ha pensado así” (p. 15).

${ }^{2}$ En carta fechada el 30 de agosto de 1920, y dirigida a su profesor Meinecke, Rosenzweig le hace saber a éste -utilizando un lenguaje metafórico- que en 1913 le aconteció un “colapso. De pronto me encontré en medio de ruinas o mejor dicho, advertí que mi camino corría entre irrealidades. ¡Justo el camino que sólo mi talento, o más bien mis talentos, me señalaban!" (Rosenzweig, 2007b, p. 86). Tal es el "medio de ruinas" o de "irrealidades" ante las que "colapsa" el pensador, que advierte que su camino - hasta ese momento- "corría entre irrealidades", que su "hambre de formas" era "insaciable", y que, obrando en consecuencia, 
decide entonces descender a la "bóveda" de su "íntimo ser", a aquel lugar en que sus “talentos" no podían seguirlo. La vuelta del autor al judaísmo supone el retorno a aquel "viejo cofre cuya existencia jamás había olvidado”, y que, había sido presente -según sus propias palabras- "en los grandes momentos de mi vida" (Rosenzweig, 2007b, p. 86). Para aquel que se interese en el mundo de la experiencia que hace eco en el autor, y poniendo el acento en el asomo del sentido común por la vía de Jerusalén, sugiero la lectura del trabajo Sentido común, filosofía y judaísmo en Franz Rosenzweig (Kuri, 2018a).

${ }^{3}$ Fragmento de carta dirigida a Martín Buber fechada el 16 de julio de 1924:

Mediante el pensamiento puede el hombre hacer penitencia realmente. En mi propia vida, la gran conversión ha tenido lugar propiamente en el terreno del entendimiento... No, nosotros no somos responsables de lo que no aprendimos o dejamos de aprender, sino por lo que pensamos o dejamos de pensar. (Díaz, 2008, p. 26)

${ }^{4}$ En la epístola que Rosenzweig dirige a su maestro Friedrich Meinecke (y a la que me referí en la nota 2), el autor judío le hace saber a éste la satisfacción que siente por haberse encontrado con sus "tesoros", con sus "bienes y legados más personales" y no con "cosas prestadas” (Rosenzweig, 2007b, p. 86). Tal es el beneplácito del pensador que, tras haberse encontrado con "sus tesoros", está dispuesto a mostrar "sus riquezas".

${ }^{5}$ La noción de antemundo es requerida a lo largo de La Estrella de la Redención para dar cuenta del sentido oculto, elemental y perpetuo de los Elementos Dios, Hombre y Mundo. Se trata de una noción que apunta a la "esencia inesencial" de los Elementos, y que supone lo previo a la esencia, lo que es de hecho condición para que ésta acontezca.

${ }^{6}$ Franz Rosenzweig distingue el paganismo creacional del paganismo histórico. De acuerdo a esta distinción, "el auténtico paganismo" es el paganismo creacional (o de la creación) que, perpetuo, sería elemental, invisible y no revelado, mientras que, el paganismo histórico, “en razón de su autonomía”, tendería hacia "algo más” que a "su ser auténtico”. Y 
esto, hasta el punto de poder constituirse en una "forma rígida", ajena a la "realidad efectiva" (Rosenzweig, 2005, pp. 38-39).

${ }^{7}$ Para Franz Rosenzweig el pensamiento pensante busca preservarse en la atemporalidad de los principios que alcanza, queriéndose conservar en la revelación del ser esencial. Su meta no admite que Dios sea Dios, que el hombre sea hombre y que el mundo sea mundo, y ello, sobre todo, porque han de reemplazarse, reduciéndose o anulándose entre sí. En fin, porque su modo de conducirse tiene por seguro que todo debe de ser algo "propiamente diferente" (Rosenzweig, 2005, p. 19).

${ }^{8}$ En La Estrella de la Redención Franz Rosenzweig pone en cuestión la filosofía de la identidad desde al menos dos direcciones (que han sido puestas de manifiesto -aunque de manera indirecta- a través del segundo -y sobre todo- tercer apartado de este trabajo). La primera, situado en el camino de la filosofía y su lenguaje (primer volumen de la obra). La segunda, apelando a una exterioridad cuyo ámbito originario sólo puede ser referido en los términos de la narración (segundo volumen de la obra). Si en la primera dirección se hace explícito el enfrentamiento directo con la filosofía especulativa alemana, y se busca por tanto mostrar la ruptura de la identidad ser y pensar en cuya unidad lo pensado se rinden en quien lo piensa, y se hace necesario - por tanto- mostrar una fractura irrecuperable capaz de mostrar las facticidades de Dios, Mundo y Hombre como protofenomenos aislados e irreductibles entre sí: en la segunda dirección la realidad acontece como realidad efectiva, se trata no de pensamiento pensante y volcado hacia sí, sino de un pensamiento hablante para el que el mundo de las cosas divinas, mundanas y humana interpelan al yo como tú. 


\section{Referencias}

Díaz, C. (2008). El Nuevo Pensamiento de Franz Rosenzweig. Salamanca: Colección persona.

Fackenheim, Emil L. (2008). Reparar el mundo. Salamanca: Ediciones Sígueme.

Hegel, G. W. F. (2008). La fenomenología del espíritu. México: Fondo de Cultura Económica.

Kuri, S. (2018a). Sentido común, filosofía y judaísmo en Franz Rosenzweig. Revista Digital FILHA. [en línea]. Julio. Número 18. Publicación bianual. Zacatecas, México: Universidad Autónoma de Zacatecas. Disponible en: www.filha.com.mx. ISSN: 2594-0449.

Kuri, Saúl. (2018b). Del inicio de la subversión del idealismo especulativo en un segmento de la "Célula originaria" de la estrella de la redención de Franz Rosenzweig. Revista Digital FILHA. [en línea]. Diciembre. Número 19. Publicación bianual. Zacatecas, México: Universidad Autónoma de Zacatecas. Disponible en: www.filha.com.mx. ISSN: 2594-0449.

Löwith, K. (2006). Heidegger, pensador de un tiempo indigente. Argentina: Fondo de Cultura Económica.

Luis Costa, M. (2000). La razón ética preoriginaria y la constitución de la subjetividad en Emmanuel Lévinas. Tesis doctoral no publicada. Universidad Nacional Autónoma de México.

Mosès, S. (1997). El ángel de la historia. España: Ediciones Cátedra.

Rosenzweig, F. (1997). La Estrella de la Redención. Salamanca: Ediciones Sígueme.

Rosenzweig, F. (2001). El libro del sentido común sano y enfermo. Madrid: Caparrós Editores.

Rosenzweig, F. (2005). El nuevo pensamiento. Argentina: Adriana Hidalgo editora.

Rosenzweig, F. (2007). Lo humano, lo divino y lo mundano. Argentina: Ed. Lilmod, Rosenzweig, F. (2007a). "Célula originaria” de la estrella de la redención. En Burello, Marcelo G. (Ed.). Lo humano, lo divino y lo mundano. (pp. 55-72). Argentina: Ed. Lilmod. 
Rosenzweig, F. (2007b). Carta a Friedrich Meinecke. En Burello, Marcelo G. (Ed.). Lo humano, lo divino y lo mundano. (pp. 83-88). Argentina: Ed. Lilmod.

Ruiz Pesce, R. E. (2005). Del Tú al Nosotros en judíos y cristianos. En Garrido-Maturano, Á. E. (Ed.). El nuevo pensamiento. (pp. 73-124). Buenos Aires: Adriana Hidalgo editora. 
Kuri, Saúl

ISSN 1405-6690 impreso

ISSN 1665-8612 electrónico 